\title{
最近の歯学
}

\section{7. 口腔細菌}

\section{口腔内から分離された Bacteroides oralis $\operatorname{Ig} 4 \mathrm{a} の$ \\ $\alpha-1.6$ glucanase 遺伝子のクローニング}

東京医科歯科大学歯学部口腔細菌学教室 高 橋 信 義, 皇 修一, 土田 信 夫

最近，遺伝子工学を利用して, Streptococcus mutans の glucosyltransferase や細胞表面抗原蛋白質などの遺 伝子を大腸菌を宿主としてクローニングすることによ り, S. mutans 遺伝子の解析, ならびに, 虫歯ワクチン 開発の研究がなされている1,2)。一方ここうした虫料口 クチンとは別に, S. mutans により産生される $\alpha-1.3$ 种 よび $\alpha-1.6$ 結合を主体とする不溶性グルカンを酵素によ り分解し, 歯后形成を抑制し, 幽周疾患を予防する研究 も試みられている。口腔内から分離した偏性嫌気性, グ ラム陰性桿菌, Bacteroides oralis Ig4a は, これら不溶 性グルカンを分解する $\alpha-1.3$ および $\alpha-1.6$-glucanase を 産生する3)。そこで，われわれは，このB. oralis Ig4aの glucanase 遺伝子のクローニングを試み, 最近得られ た, glucanase 遺伝子を発現するクローンの性質につい て述べる。

B. oralis Ig4a の染色体 DNA を Hind III で切断し, $\mathrm{pUC} 8$ をべクター, E. coli JM 105 を宿主とし，クロ一 ン・バンクを作成した。クローン・バンクから， $0.5 \%$ Blue Dextran を含む 2 YT 培地で dextran 分解能を発 現するクローンを選択し, 約 3,700のクローンのなかか ら1つのクローンを得た。このクローンは, Hind III に より， $2.7 \mathrm{~kb}$ と $4.2 \mathrm{~kb}$ 断片に切断されるプラスミドをも っており，これをプローブとして，サザン・ハイブリダ イゼーションを行った（図1)。その結果, $4.2 \mathrm{~kb}$ DNA が，B. oralis Ig4a に由来しており，この $4.2 \mathrm{~kb} \mathrm{DNA}$ 断 片中には，Eco R I, および，Bg1 II 切断部位がおのおの 1 筒所存在した。また，このクローンから産生される glucanase は，培養液中に検出され $\alpha-1.6$-glucanase 活 性を有し, 約 $45 \mathrm{~K}$ の蛋白質バンドが認められた。産生さ れる glucanase の分子量から推定し，この酵素の coding 領域は約 $1.2 \mathrm{~kb}$ 程度と考えられ，4.2kb 断片の一部が読 みとられているに過ぎナ゙，どこに， coding 領域がある のか解析中である。

口腔疾患の発症は歯垢の付着によって引きおこされ，

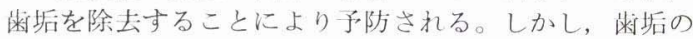
除去は， $\alpha$-1. 6-glucanase だけでは難しいといわれてい る。そこで, 現在, B. oralis Ig4a の $\alpha$-1. 3-glucanase 遗 伝子のクローニングも試みている。また，偏性嫌気性菌 の遺伝的解析は，あまり研究されておらず， B. oralis Ig 4a の glucanase 遺伝子のクローニングの成功は, 嫌気 性菌の遗伝的解析の手がかりとなる。特に㐘周病には嫌
気性菌が原因菌として考光られて扣り，これらの嫌気性 菌の病原性を解明するら光でも重要と思われる。

\section{文 献}

1) Robeson, J. P., Barletta, R. G. and Curtiss III, R. : Expression of a Streptococcus mutans glucosyltransferase gene in Escherichia coli. J. Bacteriol. 153 : 211-221, 1983.

2) Holt, R. G., Abiko, Y., Saito, S., Smoravinska, M., Hansen, J. B., Curtiss III, R. : Streptococcus mutans genes that code for extracellar proteins in Escherichia coli k-12. Infect. Immun. 38 : 147-256, 1982.

3) Takahashi, N., Satoh, Y. and Takamori, K. : Subcellular localization of D-glucanases in Bacteroides oralis Ig4a. J. Gen. Microbiol. 131 : 1077-1082, 1985.
(A)

a b c

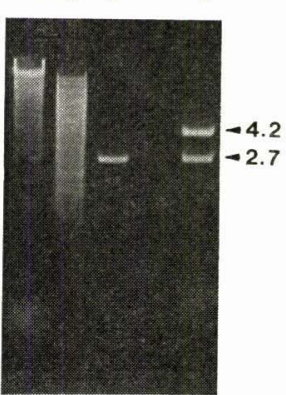

(B)

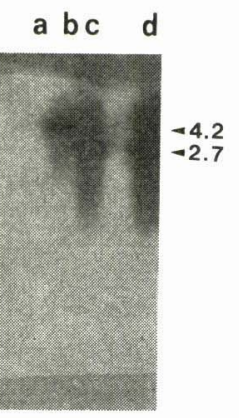

図 1 Dextran 分解能を発現するプラスミド pGL1 のアガロース・ゲル電気泳動法に よる分析

(A) DNAを臬化エチジウムで染色したもの

(B) pGL1-Hind III 切断断片を ${ }^{32} \mathrm{p}$ 標識プロ ーブよしてサザン・ハイブリダイゼーショ ンしたもの

a. Hind III で E. coli JM 105 DNA を消化 したもの

b. Hind III で B. oralis Ig4a DNA を消化 したもの

c. Hind III で pUC8を消化したもの

d. Hind III で pGLI を消化したもの 